\title{
Examining Factors Responsible for Students' Choice to Study or Work Abroad
}

\author{
Dr. Masood Ahmed, Dr. Saud Ilahi* \\ Assistant Professor, College of Business Administration, Jazan University, Al Maarefah Rd, Jazan Saudi Arabia
}

\begin{tabular}{ll}
\hline DOI: $10.36348 /$ sjef.2020.v04i03.002 & | Received: 29.02 .2020 | Accepted: 07.03 .2020 | Published: 10.03 .2020
\end{tabular}

*Corresponding author: Dr. Saud Ilahi

\section{Abstract}

Globalization and internationalization has an intense impact on the students' inclination towards the foreign environment. This research paper focuses on the factors influencing the decision of students to study or work abroad. The factors examined are: level of general knowledge (GK), attraction towards foreign study and work (AT), familiarity with the foreign environment (FM), business informative questions (BA) and repulsive factors that hold him back or create negative image of foreign society (RP). The study is conducted on 201 Saudi male undergraduate students of the Jazan University, Jazan, KSA. The result shows the propensity of students towards the foreign environment. The findings can be generalized to the majority of areas and could be used to create more focused mindset of the students for better prospects.

Keywords: Saudi Students, Study or Work Abroad, Empirical Analysis.

Copyright @ 2020: This is an open-access article distributed under the terms of the Creative Commons Attribution license which permits unrestricted use, distribution, and reproduction in any medium for non-commercial use (NonCommercial, or CC-BY-NC) provided the original author and source are credited.

\section{INTRODUCTION}

Kingdom of Saudi Arabia is unique in the sense that despite having oil money all around and rapid development in the country, it is still a developing country. KSA spends a considerable amount of money to develop its educational system; thus it is worth to identify student inclination towards the foreign environment, their ability to compete at the international level, their behaviour to accept the changes and its implication on them [1]. The objective of the study is to identify factors that are responsible for student choice to study or work overseas. The research focuses on five factors namely: level of general knowledge (GK), attraction towards foreign study and work (AT), familiarity with the foreign environment (FM), Business informative questions (BA) and factors that create a negative image of foreign society as a repulsive factor (RP) [2]. The study is conducted in Jazan University in the Jazan Province that is nearer to the border of Yemen and the city lags in terms of facilities and the educational environment as compared to other old universities in KSA in metro cities. Thus the finding can be generalized to the majority of areas outside the metro cities and could be used to create more focused mindset of the students for their better future.

\section{LITERATURE REVIEW}

This section reviews the literature on factors that are responsible for students' choice to study or work abroad with an emphasis on students' decision making power.

Mazzarol \& Soutar worked upon the Pull theory which is related to attraction factors that make the host country more appealing to students. They discovered that the factors like academic environment, recommendation from friends and relatives, support for international students and the students themselves affect the choice to pursue education overseas [3]. Pimpa, argued that the opinion of family members may affect the behavior of an individual in various ways, so the impact of the family is one of the dominant factor in making the decision of studying abroad [4]. In another study Shank, Quintal and Taylor, found that while determining for pursuing study overseas, $37 \%$ of international undergraduate students chose their parents and friends as the dominant factor [5]. Margine propounded in his article that students are more focused on educational cost which make them more responsible as a result they expect to generate higher income in future [6]. In recent study Lee found that the particular section of the students is not satisfied with the education quality of the home country and long for better quality higher education abroad [7]. 


\section{Experimental Section}

\section{METHODOLOGY}

To examine the respondents' inclination towards working or studying abroad both primary and secondary data was employed. The survey method was applied to collect the primary data through close-ended questionnaire, [8] where respondents inclination towards working or studying abroad is used as the dependent variable and measured against the factors that may affect his decision like attraction towards foreign study and work (AT), familiarity with foreign environment (FM), Business informative questions (BA), level of general knowledge (GK) and repulsive factors that hold him back or create negative image of foreign society(RP). Besides this the secondary data was collected from different sources, i.e. journals, industry reports, theses, books and websites.

\section{Sample Size}

For the study, the sample size comprises of 201 Saudi male undergraduate students of the Jazan University, Jazan, KSA. The respondents belong to five different streams namely, Business Administration, Computer Science, English \& Mathematics, Engineering and Medical Science. Each category consists of at least 40 students. Responses were collected through volunteer students of the above said streams.

\section{Questionnaire}

The questionnaire consists of six sections. Section one is designed to collect general information like age and respondents willingness to study or work in a foreign country and his inclination to learn a foreign language for the purpose.

Section two comprises of questions where respondents' understanding of business is measured by simple business informative questions (BA). Section three consists of questions which measure the attraction towards the foreign study and work (AT). Section four is about the respondents familiarity with the foreign environment (FM). Section five measures the level of general knowledge (GK) and section six focuses on repulsive factors (RP), where students were questioned about the barriers or difficulty they feel in taking decision and factors that create a negative image of a foreign society.

The dependent variable (DV) for research is respondent's choice whether he is interested in going abroad for study or job (Respondent Y) or not (Respondent $\mathrm{N}$ ) after that five independent variable factors are measured based on the collected data.

Table-1: Factors with motive and expected output

\begin{tabular}{|l|l|l|}
\hline Factors & Motive or Reason for asking & Expected Informative output \\
\hline $\begin{array}{l}\text { Business } \\
\text { Questions (BA) }\end{array}$ & $\begin{array}{l}\text { To ascertain respondent's ability to diagnose } \\
\text { the international business environment and } \\
\text { its importance. }\end{array}$ & $\begin{array}{l}\text { The data is expected to provide the difference } \\
\text { in the level of business understanding between } \\
\text { the respondent Y and respondent N }\end{array}$ \\
\hline $\begin{array}{l}\text { Attraction Factor } \\
\text { (AT) }\end{array}$ & $\begin{array}{l}\text { To find out how respondent evaluates } \\
\text { different factors that attract them, in the } \\
\text { selection of foreign study or foreign job } \\
\text { opportunities. }\end{array}$ & $\begin{array}{l}\text { It is anticipated to get the answer of how two } \\
\text { groups i.e. respondent Y \& respondent N } \\
\text { perceive different factor of attraction in their } \\
\text { choices. }\end{array}$ \\
\hline $\begin{array}{l}\text { Familiarity Factor } \\
\text { (FM) }\end{array}$ & $\begin{array}{l}\text { To discover the level of familiarity with the } \\
\text { international environment. }\end{array}$ & $\begin{array}{l}\text { The data is supposed to reveal the respondents' } \\
\text { Y \& N, level of familiarity with international } \\
\text { environment and how they perceive it? }\end{array}$ \\
\hline $\begin{array}{l}\text { General } \\
\text { Knowledge Factor } \\
\text { (GK) }\end{array}$ & $\begin{array}{l}\text { To find out the level of general knowledge } \\
\text { between the two groups. }\end{array}$ & $\begin{array}{l}\text { The data is expected to provide how these two } \\
\text { groups differ in their knowledge, and what is } \\
\text { the impact on their choices. }\end{array}$ \\
\hline $\begin{array}{l}\text { Repulsive Factor } \\
\text { (RP) }\end{array}$ & $\begin{array}{l}\text { To judge the different barriers if exist for } \\
\text { respondents, that make foreign work or } \\
\text { study difficult for them. }\end{array}$ & $\begin{array}{l}\text { It is envisioned to get the information that how } \\
\text { respondents perceive different barriers in their } \\
\text { choices. }\end{array}$ \\
\hline
\end{tabular}

\section{Procedure}

\section{Initial Questionnaire Design}

Initial questionnaire was designed in consultation with the Saudi Student Committee, who was aware of the Saudi respondents' mindset. On their suggestions, five independent factors were selected for measuring the choice of respondents who want/don't want to go abroad for either study or work.

\section{Pre-Testing of Questionnaire and changes applied}

The questionnaire was tested on a section of respondents to find out its validity for the desired objective. After pre-testing, it was decided that there was a need to simplify the language of the questionnaire and to reduce the number of questions as all the students were undergraduates, having limited level of understanding. Moreover, they exhibited less interest in applying their minds for complicated issues and devoting more than 15 minutes for a questionnaire. Subsequently, the questionnaire was translated into Arabic and got it verified from the Arabic language department before its distribution for data collection. 


\section{Data Collection}

The questionnaire was administrated to the Jazan University undergraduate students of different colleges after assuring them of their anonymity and promising them that the data would be used for academic purpose only. Student Volunteer was chosen and trained to explain the questionnaire items in details to all the respondents before asking them to fill the details. Utmost care was taken to provide clear and straightforward instructions for the collection of data. Standard procedure was followed for data collection, data scrutiny and data inputs after proper coding for SPSS analysis.

\section{RESULTS AND DISCUSSION}

The age of respondents has been between 16 to 28 years, in which majority falls between 20 to 24 years $(70 \%)$, succeeded by the age group of 16-19 years (14\%) while $8 \%$ have not mentioned their age. Percentage of respondents $\mathrm{Y}$, who are eager to study or work in foreign conditions is $78 \%$, while respondents $\mathrm{N}$, who are not eager or willing to go abroad being $22 \%$. In this research, we focus on the characteristics of respondents $\mathrm{Y}$ and $\mathrm{N}$ and their choices under different measurable factors.

Analysis of data confirms that respondents Y who are eager to travel abroad for study or work purpose, also willing to learn a foreign language (90\%), even respondents $\mathrm{N}(72 \%)$ think that learning a foreign language is an added advantage that will help them in future. Chi-square test results are significant $X^{2}(1)=$ $8.460, \mathrm{p} \leq .05$. So we can clearly state there is a significant relationship between respondents $\mathrm{Y}$ and their inclination to learn a foreign language for future prospects.

\section{Analysis of GK Factor}

Overall, $58(29 \%)$ respondents answer all four GK questions correctly, 27\% answer three questions while $29 \%$ answer only two questions correctly. It is observed that out of 201 respondents 58 respondents answer all four questions correctly out of that 52 belongs to respondents Y category (90\%), it shows that respondents who are eager and interested to go abroad are more informed in comparison of those who do not want to go abroad.

The data also shows that Saudi students are not well informed as they have not been able to answer few simple questions correctly, like the name of the founder of Facebook, although they might have been the active users of Facebook, despite that $69 \%$ respondents answer it correctly. $59 \%$ respondents know that Nepal is the country that suffered due to major earthquake in 2015, 49\% know that Panda bear belongs to China and $89 \%$ answer correctly about the President of the USA.

The Table-2 provides a comparison between respondents $\mathrm{Y} \& \mathrm{~N}$, and what percentage of them answers the GK questions correctly. The data states respondents $\mathrm{Y}$ are more informed, even if we take frequency in place of percentage we observe that 76 respondents $\mathrm{Y}$ (out of 157) correctly answer the question as compared to 22 respondents N. Percentage figure doesn't depict the complete picture as overall frequency of respondents $\mathrm{N}$ (43) is less in numbers.

Table-2: Percentage of respondents answered correctly

\begin{tabular}{|l|l|l|l|l|}
\hline Percentage/Frequency & GK1 & GK2 & GK3 & GK4 \\
\hline Respondents Y & $72 \%(113)$ & $66 \%(103)$ & $48 \%(76)$ & $90 \%(142)$ \\
\hline Respondents N & $61 \%(26)$ & $35 \%(15)$ & $51 \%(22)$ & $86 \%(37)$ \\
\hline
\end{tabular}

\section{Analysis of Business Informative Questions}

This section focuses on ability of respondents to diagnose international environment opportunities. The first question demands them to select the factor which is more important to be a successful businessman at international level, $47 \%$ of respondents $\mathrm{Y}$ state that knowledge of foreign culture and business environment is more important, while $31 \%$ of them give credit to personal abilities and capability to adjust in foreign environment and $12 \%$ state government promotional schemes mark the international success.

The second question enquires regarding the source of their knowledge about foreign business environment, $68 \%$ of respondents $\mathrm{Y}$ state, they depend on internet for information, $20 \%$ pick news and media channels as the source. On the other hand, $42 \%$ respondents $\mathrm{N}$ opt for internet and $37 \%$ for news channels as the source of their information.
In question three, students express their opinion about Saudi companies, should they open their business/industrial units in other countries. Option-1- is related to respondents' agreement with the statement, whereas other favourable option-4 is directly linked with equal trade treatment at international level. The respondents who select option $1 \& 4$ are more in favour of liberalization and free trade practices .Option-2 is concerned with rejection of idea and option-3 is linked with foreign companies' investment in KSA, these accumulate under the conservative view category. The analysis of data shows that respondents Y, selecting option 1 \& 4 have been $40 \%$ and $44 \%$ respectively, while respondents $\mathrm{N}$ choosing for option $1 \& 4$ being $40 \% \& 30 \%$. On the other hand $30 \%$ of respondents $\mathrm{N}$ opt for conservative option $2 \& 3$, while $16 \%$ of respondents $\mathrm{Y}$ opt for the same. Chi-square test results are significant $\mathrm{X}^{2}(3)=13.047, \mathrm{p} \leq .05$. So there is a significant relationship between respondents $\mathrm{Y}$. It shows that respondents $\mathrm{Y}$ are more informed, who can 
utilize information in their decision to choose overseas as an option.

\section{Analysis of Factors of Attraction}

The first question under the factor of attraction probes into respondents' leaning towards various reasons for choosing an overseas career. It includes gaining foreign work experience, higher salaries, promotion and more top earnings opportunities and international culture. Respondents $\mathrm{Y}$ give preference to foreign work experience (42\%) followed by other factors like promotional chances \& higher earnings opportunities (32\%), foreign culture $(19 \%)$ and higher salaries $(6.5 \%)$. While respondents $\mathrm{N}$, give more weight to foreign culture $(45 \%)$ than anything else, second to them is promotional chances and higher earnings opportunities $(23 \%)$, followed by work experience $(19 \%)$ and salary (13\%).

The second question seeks their opinion about the western culture. As expected overall 57\% respondents agree that western culture is good in which $61 \%$ respondents Y clearly state their choice, but $22 \%$ do not want to express their opinion, whereas only $17 \%$ assume western culture bad but still wish to avail opportunities to study and work in a foreign country. Even respondents $\mathrm{N}$, are not openly against western culture as $42 \%$ consider good and $19 \%$ limit themselves in expressing their choice while merely $40 \%$ state that it is bad.

The third question probes into the specific factors that they consider good in the western countries, $38 \%$ of respondents $\mathrm{Y}$ vouch for education system, followed by lifestyle (24\%), freedom of expression (19\%), money (5\%) and only $14 \%$ state that there is nothing good in foreign countries. Respondents $\mathrm{N}$ also select education system (33\%) as their first choice, followed by nothing is good $(28 \%)$ in foreign countries and lifestyle (19\%), money (12\%) and freedom of expression as their last choice (9\%). The stark choice is freedom of expression where respondents $\mathrm{Y}$ put it in third place, and respondents $\mathrm{N}$ put in on the fifth and last place. Chi-square test results are significant $X^{2}(3)=$ $12.941, \mathrm{p} \leq .05$, stating that respondents choice is not independent of the attraction factor.

\section{Analysis of Factors of Familiarity}

Under these factors of familiarity, Respondents Y (41\%) favourite destination is Europe followed by USA (23\%), Australia \& New Zealand (19\%), Asia $(11 \%)$ and the middle-east $(6 \%)$, even respondents $\mathrm{N}$ consider Europe (47\%) as their first choice.

In regard to knowledge pertaining to the foreign culture \& environment, $70 \%$ of respondents Y choose very good and good option as compared to $65 \%$ respondents $\mathrm{N}$. The difference is not visible in percentage but in frequency, 109 respondents $\mathrm{Y}$ choose very good and good option to describe their knowledge as compared to 28 respondents $\mathrm{N}$.

The next question probes into the reason behind their willingness to understand foreign culture and business environment, surprisingly $60 \%$ of respondents ( $\mathrm{Y} \& \mathrm{~N}$ ) agree for self- development while $36 \%$ admit for country's development, so both the groups have almost same selection of choices.

The next question investigates about the peoples' opinion about them in foreign countries. 54\% respondents $\mathrm{Y}$ reply that they will be treated as tourist, and $18 \%$ believe that they will be treated as one of them while $18 \%$ state that people in west will maintain distance in interacting with them and only $10 \%$ of them feel westerners are afraid of them. Chi-square test results are significant $\mathrm{X}^{2}(3)=10.176, \mathrm{p} \leq .05$. Therefore, we have strong reason to believe that a positive feeling about foreign treatment has significant impact over the choice to go abroad.

\section{Analysis of Factor of Repulsion}

The analysis reveals that Respondents $\mathrm{Y}$ who want to go abroad assume western lifestyle (32\%) as a major barrier and they find themselves misfit for the challenge. Secondly, they blame foreign environment (24\%) which is highly competitive environment with too many restrictions. Thirdly they think that lack of reciprocal cultural knowledge (23\%) makes the things difficult to accept for each other when working or studying in a foreign environment and lastly they accept that their family and friends $(21 \%)$ do not want them to go overseas. Respondents $\mathrm{N}$ also admit western lifestyle $(41 \%)$ as a major factor of repulsion.

In regard to major hindrance for building friendly relations with foreign nationals, respondents $\mathrm{Y}$ state language barrier (45\%) as the biggest challenge. Secondly, they think that cultural difference (20\%) makes it difficult to accept each other, while they give almost equal weight i.e. $17 \%$ \& $18 \%$ to difference in religion $\&$ beliefs and different lifestyle respectively.

The next question enquires the factors that they consider bad in foreign culture. Respondents $\mathrm{Y}$ consider freedom of expression (26\%) bad as everything is acceptable under it. Secondly, $11 \%$ blamed foreign lifestyle followed by too much money $(9 \%)$ then education system $(3 \%)$, but $51 \%$ of the respondents have strong belief that nothing is wrong when they have opted to work or study abroad. Chisquare test results are significant $\mathrm{X}^{2}(2)=9.685, \mathrm{p} \leq .05$, expressing the significant relationship between the variables.

\section{CONCLUSION}

The analysis of data establish the fact that the respondents $\mathrm{Y}$ who want to study or work abroad want to learn a foreign language, moreover their general 
knowledge is better than respondents $\mathrm{N}$, which has been developed by extensive use of internet. They want to go overseas to get better education and to gain foreign work experience which will come up with superior future prospects and higher earnings. Their approach is favourable regarding the impact of western culture and assume that they will be treated as a tourist when move abroad for study or work. Overall they have a positive outlook that has a significant relationship with their choice to prefer an overseas destination for better prospects.

\section{REFERENCES}

1. Kainuwa, A., \& Yusuf, N. B. M. (2013). Influence of socio-economic and educational background of parents on their children's education in Nigeria. International journal of scientific and research publications, 3(10), 1-8.

2. Salisbury, M. H. (2011). The effect of study abroad on intercultural competence among undergraduate college students, University of Iowa, University of Iowa.
3. Mazzarol, T., \& Soutar, G. N. (2002). Push-pull" factors influencing international student destination choice. International Journal of Educational Management, 16(2):82-90.

4. Pimpa, N. (2003). The Influence of Family on Thai Students' Choices of International Education. International Journal of Educational Management, 17(5):211-219.

5. Shanka, T., Quintal, V., \& Taylor, R. (2005). Factors Influencing International Students' Choice of an Education Destination-A Correspondence Analysis. Journal of Marketing for Higher students- Education, 15(2):31-46.

6. Maringe, F. (2006). University and course choice: Implications for positioning, recruitment and marketing. International Journal of Educational Management, 20(6):466-479.

7. Lee, S. W. (2017). Circulating East to East: Understanding the Push-Pull Factors of Chinese Students Studying in Korea. Journal of studies in international education, 21(2):170-190.

8. Fanning, E. (2005). Formatting a Paper-based Survey Questionnaire: Best Practices Practical Assessment Research \& Evaluation, 10(12). 